prof. dr hab. inż. Janusz, Mielniczuk

Politechnika Poznańska

Instytut Pojazdów Szynowych , TABOR”

mgr inz. Pawel Kuligowski

Instytut Pojazdów Szynowych , TABOR”

\title{
Konstrukcja dachu wagonu pasażerskiego z zastosowaniem materialu o strukturze porowatej
}

\begin{abstract}
$W$ artykule omówiono kolejny wariant możliwości zastosowania elementów powierzchniowych o strukturze porowatej w budowie dachu wagonu kolejowego. Zaproponowano wprowadzenie powtoki porowatej o większej grubości, ograniczajac udziat dotychczasowego szkieletu stalowego. Przeprowadzono analize wytrzymałości tak zaprojektowanego fragmentu dachu. W artykule zestawiono porównanie wyników z rezultatami analiz klasycznego rozwiazania konstrukcji dachu.
\end{abstract}

\section{Wprowadzenie}

Praca stanowi kontynuację wcześniej podjętych i opublikowanych badań [ $\left[\begin{array}{lll}1 & \text { i } & 2\end{array}\right]$. Tematyką ich są rozważania dotyczące możliwości zastosowania materiałów konstrukcyjnych o strukturze porowatej w budowie maszyn, z ukierunkowaniem na pojazdy szynowe.

$\mathrm{W}$ [2] omówiono rezultaty analizy wytrzymałości fragmentu dachu wagonu pasażerskiego, w którym klasyczną jednorodną stalową blachę poszyciową o grubości $1,5 \mathrm{~mm}$ zastąiono powłoką o strukturze porowatej, przy czym szkielet pozostaje nienaruszony. Własności mechaniczne materiału porowatego (moduł Young'a i współczynnik Poisson'a) przyjęto takie jak dla stali. Wyniki tych analiz dowodzą, że zastosowanie porowatych materiałów powoduje między innymi obniżenie masy konstrukcji dachu. Grubość proponowanej powłoki o strukturze porowatej, gwarantującej przeniesienie rozpatrywanych obciążeń, wynosi maksymalnie $2,5 \mathrm{~mm}$ przy porowatości $\mathrm{e}_{0}=0.99$, przy czym mimo wzrostu grubości powłoki następuje obniżenie jej masy (maksymalnie do około $60 \%$ masy powłoki klasycznej).

Kontynuując wyżej omówione prace w artykule przeanalizowano możliwości zastosowania w konstrukcji dachu grubszej powłoki o strukturze porowatej, przy jednoczesnej rezygnacji ze szkieletu stalowego. Ze względu na masę, wskazanym byłoby wykorzystanie do budowy struktury powłoki materiału w postaci spienionego aluminium.

\section{Obciążenia i modele obliczeniowe}

W celu umożliwienia porównywania wyników analizy z dotychczasowymi [2], do zamodelowania przyjęto analogiczny pod względem wymiarowym fragment konstrukcji dachu wagonu. Uwzględniono również identyczne obciążenie (pochodzące od zalegającego na dachu śniegu).
Własności materiałowe powłoki, zmienne na grubości przekroju poprzecznego, zostały zamodelowane w podobny sposób jak w [2] za pomocą szeregu warstw o stałej grubości oraz o stałych wskaźnikach mechanicznych. Zmianę własności mechanicznych na poszczególnych warstwach przedstawiono w [2].

Wstępny model obliczeniowy obejmował podłużnicę dachową, stanowiącą element łączący dach ze ścianą boczną i powłokę o strukturze porowatej. Z pozostałej części szkieletu zrezygnowano. Model fragmentu dachu przedstawiono na rys.1.

Badania wykonano metodą elementów skończonych (MES) z wykorzystaniem programu ABAQUS. $\mathrm{W}$ modelu uwzględniono symetrię występująca $\mathrm{W}$ rzeczywistej konstrukcji. Na podłużnicy dachowej w miejscu podparcia na ścianie bocznej wprowadzono możliwość przesunięcia w kierunku poprzecznym, a krawędzie powłoki kończące model utwierdzono na przemieszczenia w kierunku wzdłużnym i obrót względem osi poprzecznej. Obciążenie śniegiem przyłożono na takiej samej powierzchni jak w poprzedniej analizie [2].

Do analizy zastosowano element powłokowy typu S8R, jednorodny przekrój powłokowy dla podłużnicy dachowej oraz wielowarstwowy (złożony) przekrój powłokowy dla powłoki porowatej.

Badania wykonano dla następujących danych: podhużnica dachowa $E=2,05 \cdot 10^{5} \mathrm{MPa}, v=0,3$, powłoka walcowa $\mathrm{E}_{1}=0,7 \cdot 10^{5} \mathrm{MPa}, \nu=0,3$.

Badania przeprowadzono $\mathrm{w}$ celu określenia wpływu grubości powłoki na sztywność dachu dla poszczególnych porowatości: $\mathrm{e}_{0}=0,45 ; 0,60 ; 0,75$; 0,$90 ; 0,99$.

Na podstawie wstępnych wyników można stwierdzić, że dla rozpatrywanego modelu obciążonego śniegiem, przemieszczenia $\mathrm{w}$ kierunku pionowym $\mathrm{i}$ poprzecznym są bardzo duże i kilkunastokrotnie prze- 
kraczają dotychczasowe. Spowodowane to jest sposobem podparcia modelu na ścianie bocznej, a zwłaszcza możliwością przesunięcia w kierunku poprzecznym podłużnicy dachowej. Uniknięcie tej niedogodności wymagałoby uwzględnienia wpływu ściany bocznej na takie zachowanie, co wiąże się z rozbudową modelu, ale przede wszystkim uniemożliwia porównywanie wyników $\mathrm{z}$ dotychczas wykonanymi analizami.

Wobec powyższego, w celu zagwarantowania porównywalności wyników, zaproponowano rozwiązanie pośrednie, zmieniające koncepcję konstrukcji dachu. W celu zwiększenia sztywności powłoki pozostawiono część szkieletu o znacznie zmienionej konstrukcji. Zrezygnowano z podłużnic wzmacniających powłokę dachową. Ograniczono ilość krokwi pozostawiając tylko te na przedłużeniu słupków ściany bocznej oraz ograniczono ilość ściągów poprzecznych. Ponadto przekrój poprzeczny krokwi zredukowano do ceownika (w dotychczasowej konstrukcji był zetownik).

Model zaproponowanego rozwiązania przedstawiono na rys.2. Zastosowane elementy skończone, warunki brzegowe, obciążenia oraz dane materiałowe są identyczne jak w modelu wstępnym omówionym powyżej.

\section{Omówienie wyników analizy}

Na rys.3 i 4 zamieszczono przykładowe rozkłady przemieszczeń pionowych UZ i poprzecznych UY powstających $\mathrm{w}$ rozpatrywanym modelu od obciążenia śniegiem.

Na rys.5 i 6 przedstawiono w postaci wykresów stosunki przemieszczeń powłoki o strukturze porowatej do przemieszczeń powłoki jednorodnej (o grubości $1,5 \mathrm{~mm}$ ), odpowiednio $\mathrm{w}$ kierunku pionowym i poprzecznym, w funkcji grubości powłoki dla poszczególnych porowatości.

Podobnie jak w przypadku analizy wytrzymałości dachu, omówionego w [2], konstrukcja z grubszą powłoką o strukturze porowatej jest również wrażliwa na przemieszczenia poprzeczne. W stosunku do konstrukcji dachu z powłoką jednorodną przemieszczenie poprzeczne jest prawie 3,1 raza większe dla współczynnika porowatości $\mathrm{e}_{0}=0,99$ i grubości $3 \mathrm{~mm}$ i spada do 1,44 raza dla współczynnika porowatości $\mathrm{e}_{0}=0,45 \mathrm{i}$ grubości $15 \mathrm{~mm}$. Są to wyniki porównywalne $\mathrm{z}$ uzyskanymi dla rozwiązania przedstawionego $\mathrm{w}$ [2].

Natomiast $\mathrm{w}$ przypadku przemieszczeń pionowych uzyskane wyniki są znacznie bliższe rezultatom dla powłoki jednorodnej. Dla współczynnika porowatości $\mathrm{e}_{0}=0,99$ i grubości powłoki $3 \mathrm{~mm}$ przemieszczenia pionowe są około 1,26 raza większe niż dla powłoki jednorodnej, ale dla $\mathrm{e}_{0}=0,45$ i grubości $15 \mathrm{~mm}$ są już mniejsze około 1,34 raza.
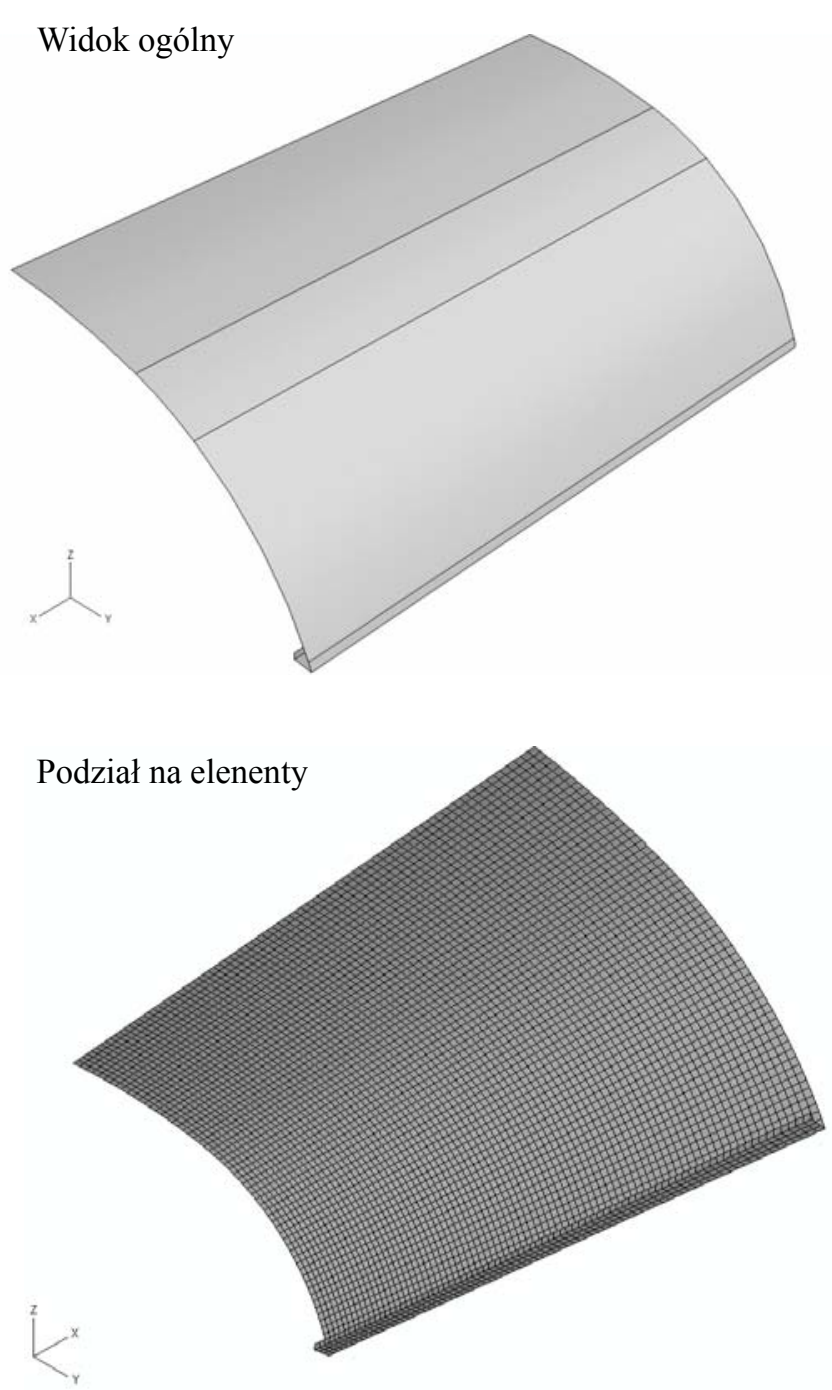

Rys.1. Model fragmentu konstrukcji dachu (bez dotychczasowego szkieletu)

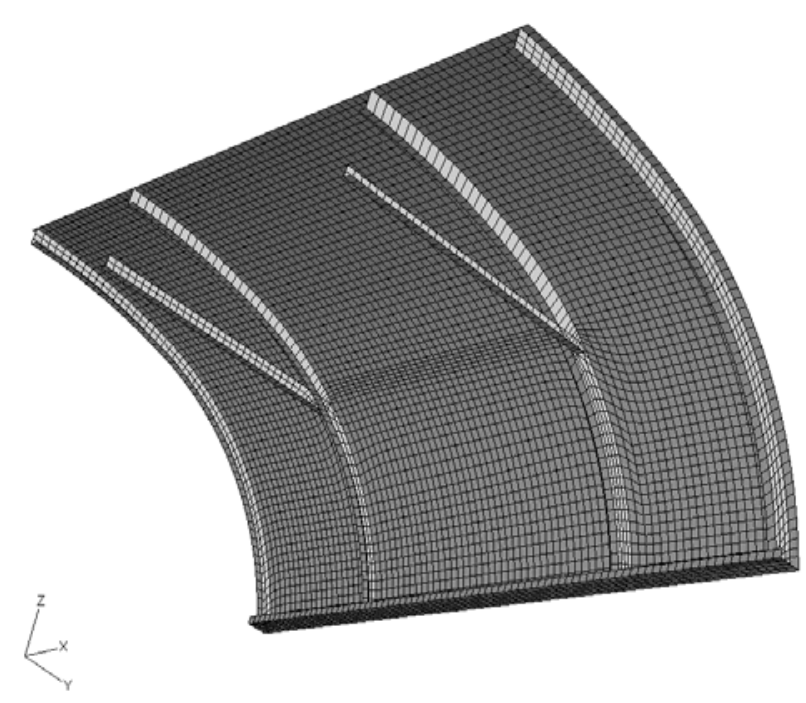

Rys.2. Model fragmentu dachu wzmocnionego szkieletem podział na elementy 


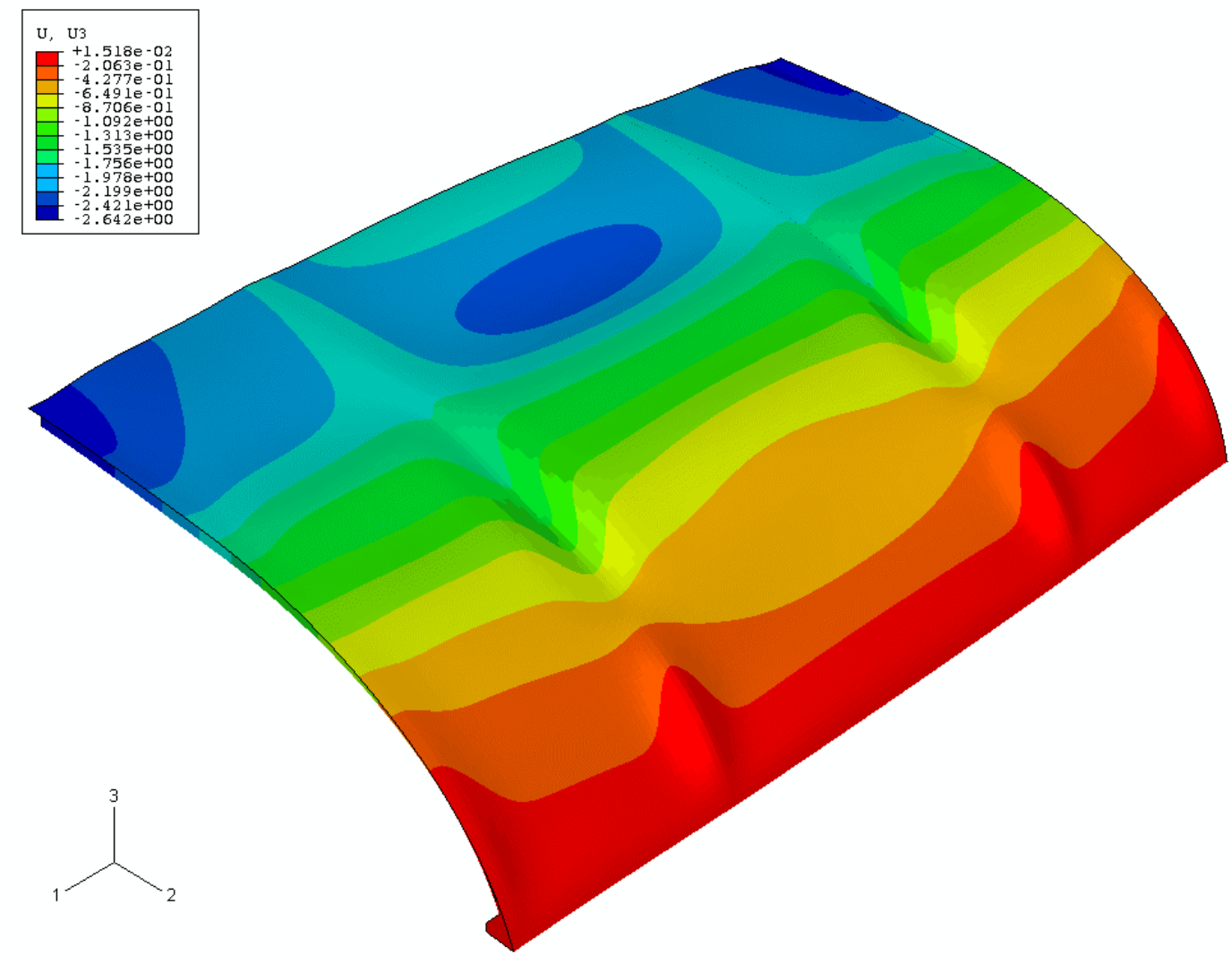

Rys.3. Przykładowy rozkład przemieszczeń UZ [mm] w kierunku pionowym

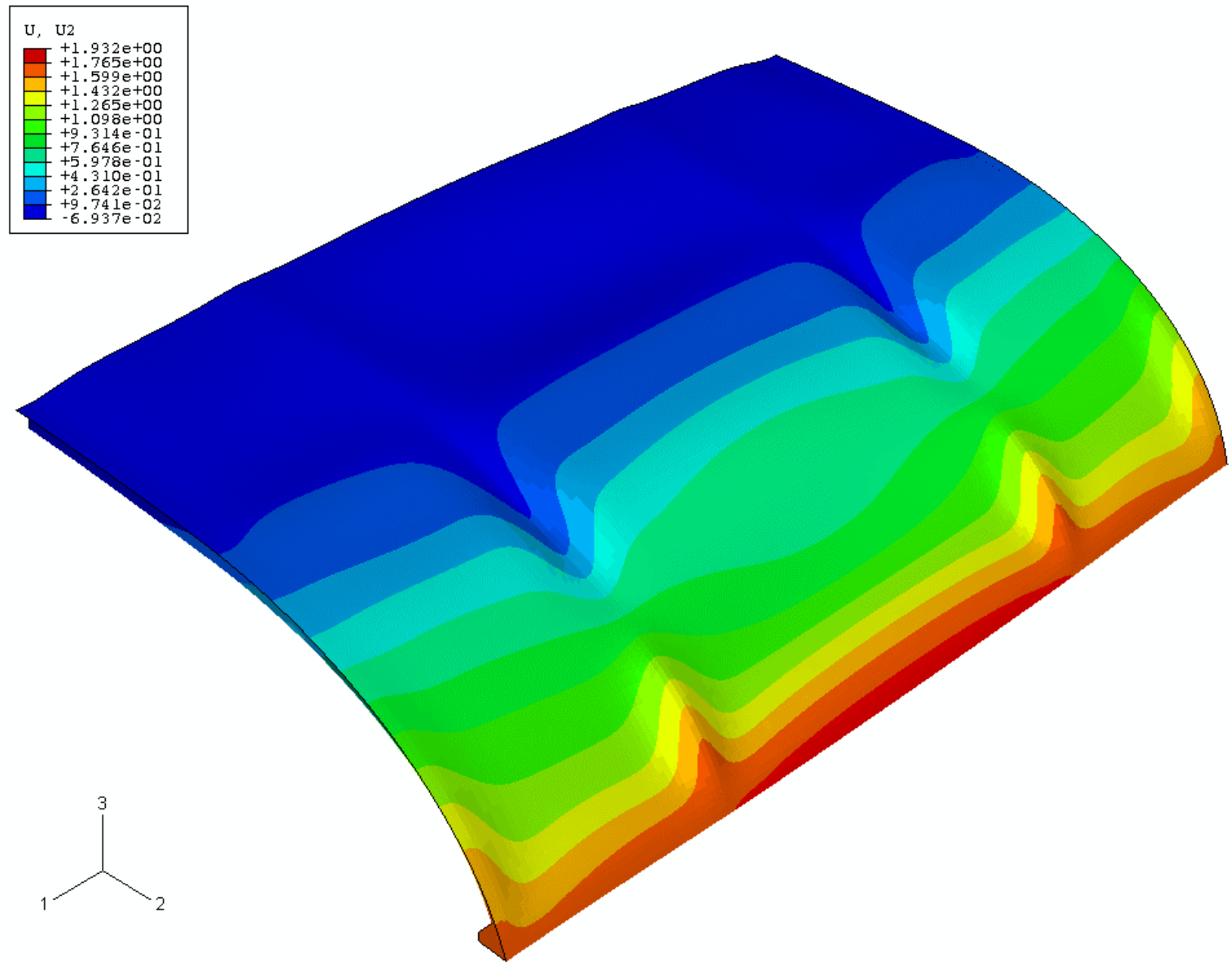

Rys.4. Przykładowy rozkład przemieszczeń UY [mm] w kierunku poprzecznym 


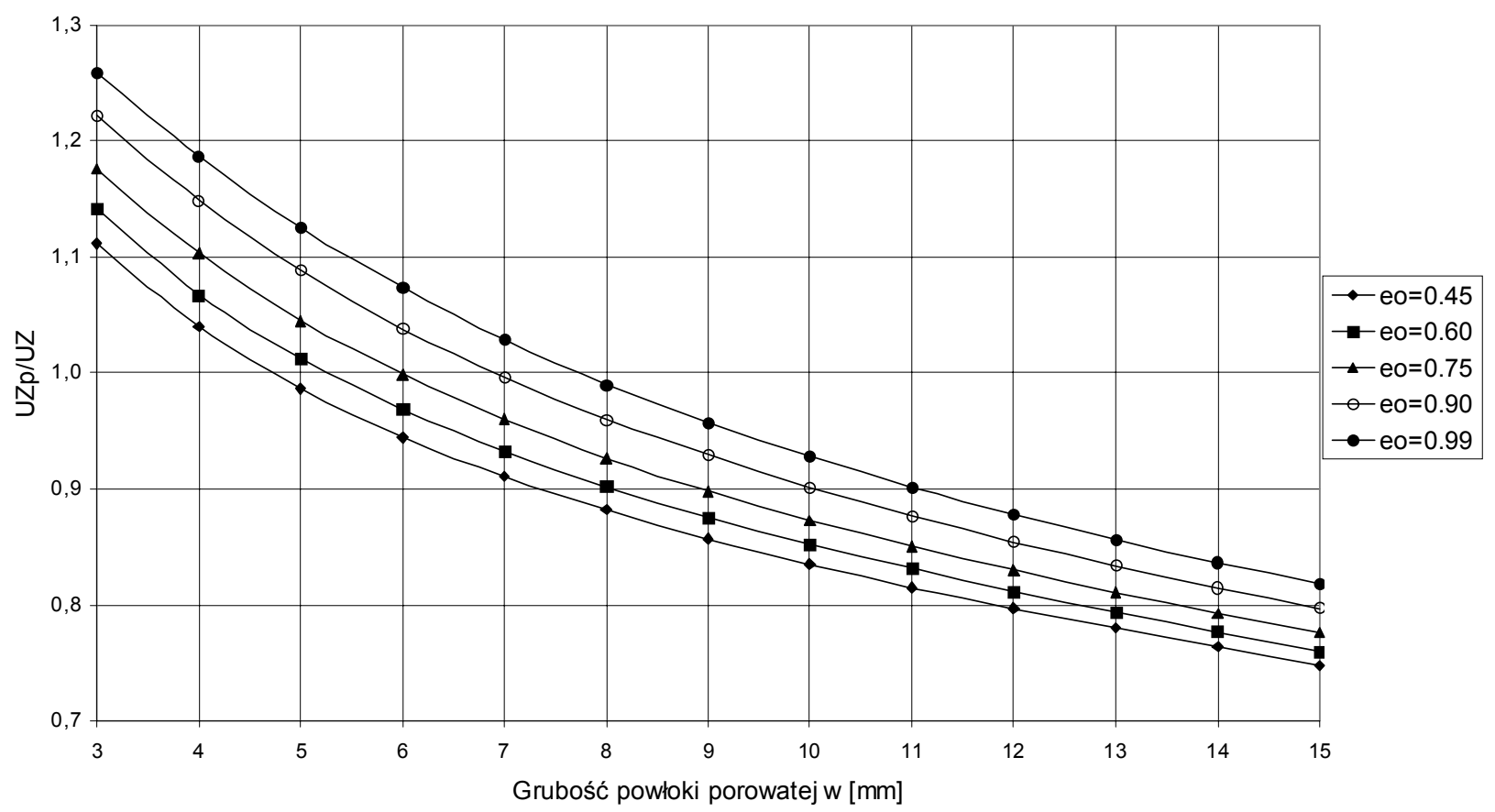

Rys.5. Stosunek przemieszczeń pionowych konstrukcji dachu z powłoką porowatą do konstrukcji z powłoką jednorodną $\mathrm{UZp} / \mathrm{UZ}$ w funkcji grubości powłoki dla wybranych porowatości $\mathrm{e}_{0}$

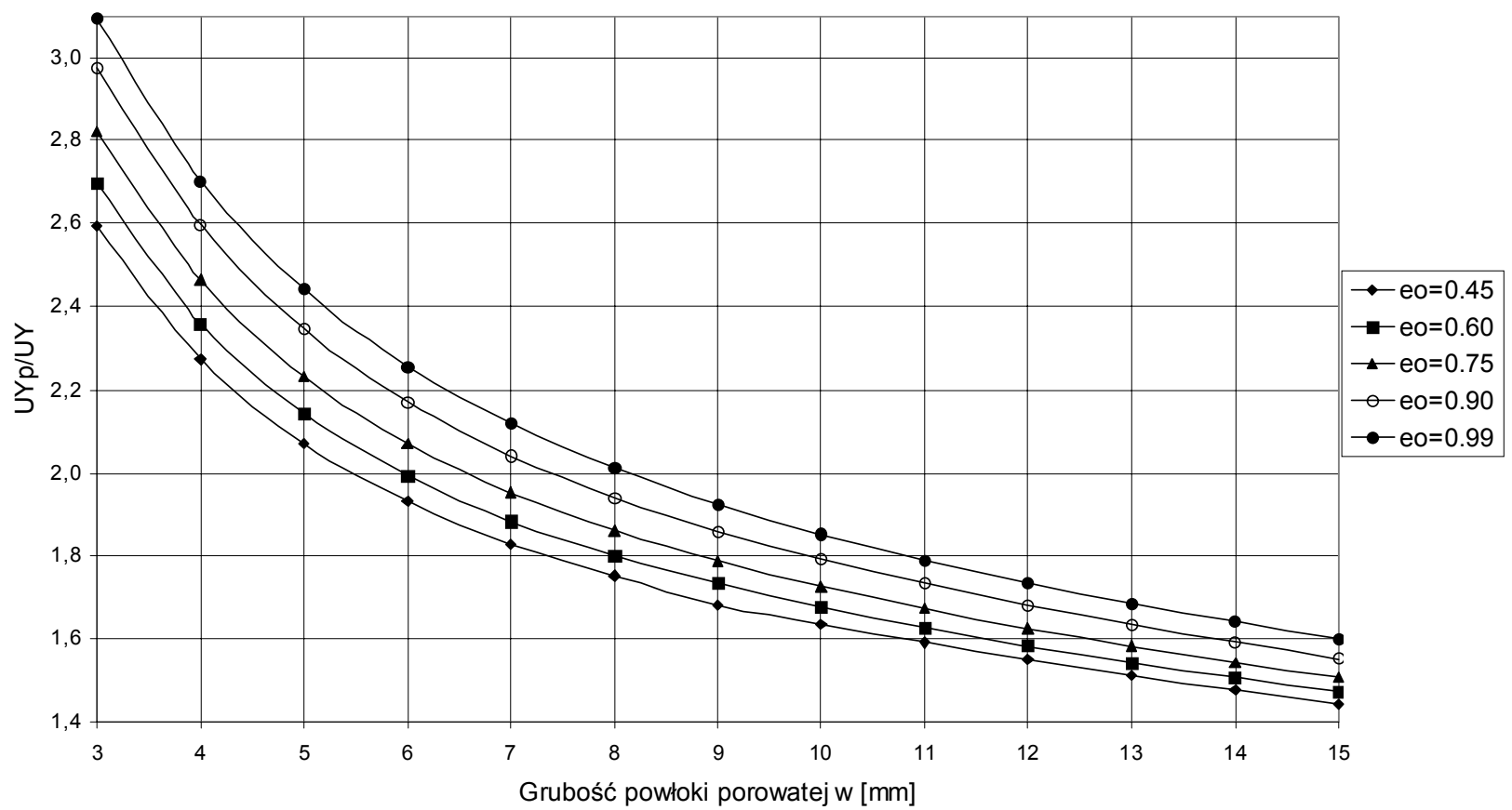

Rys.6 Stosunek przemieszczeń poprzecznych konstrukcji dachu z powłoką porowatą do konstrukcji z powłoką jednorodną UYp/UY w funkcji grubości powłoki dla wybranych porowatości $\mathrm{e}_{0}$

W tabeli 1 zestawiono wyniki obliczeń grubości powłoki porowatej $t_{p}$ oraz stosunki mas rozpatrywanego fragmentu dachu z powłoką porowatą $m_{p}$ i jednorodną $m$ dla różnych współczynników porowatości przy założeniu, że sztywność w kierunku pionowym obu rozwiązań jest jednakowa. Z tabeli wynika, że wraz ze wzrostem współczynnika porowatości rośnie grubość powłoki porowatej $t_{p}$ (około 1,64 raza w rozpatrywanym zakresie). Mimo to dla rozpatrywanych współczynników porowatości i grubości powłoki masa konstrukcji dachu z powłoką porowatą $m_{p}$ jest mniejsza od klasycznej $m$ i w zależności od współczynnika porowatości stanowi od $68 \%$ do $73 \%$ masy klasycznej. 
Grubości powłoki porowatej oraz stosunki mas konstrukcji dachu z powłoką porowatą i jednorodną przy jednakowym przemieszczeniu pionowym

Tabela 1

\begin{tabular}{|c|c|c|c|c|}
\hline L.p. & $\begin{array}{c}\text { Wspótczynnik po- } \\
\text { rowatości }\end{array}$ & $t_{p}[\mathrm{~mm}]$ & $\mathrm{m} / \mathrm{m}_{p}$ & $m_{p} / \mathrm{m}$ \\
\hline 1 & $\mathrm{e}_{0}=0,45$ & 4,7 & 1,367 & 0,731 \\
\hline 2 & $\mathrm{e}_{0}=0,60$ & 5,3 & 1,379 & 0,725 \\
\hline 3 & $\mathrm{e}_{0}=0,75$ & 6,0 & 1,406 & 0,711 \\
\hline 4 & $\mathrm{e}_{0}=0,90$ & 6,9 & 1,444 & 0,692 \\
\hline 5 & $\mathrm{e}_{0}=0,99$ & 7,7 & 1,461 & 0,684 \\
\hline
\end{tabular}

\section{Wnioski}

Z uzyskanych rezultatów wynika, że w rozpatrywanym fragmencie konstrukcji dachu wagonu pasażerskiego, przy działaniu obciążenia pochodzącego od zalegającego śniegu, nie można $\mathrm{z}$ punktu widzenia wytrzymałości całkowicie zrezygnować ze szkieletu stalowego. Mimo to masa proponowanego rozwiązania jest mniejsza od masy klasycznej konstrukcji dachu.

$\mathrm{Na}$ podstawie analizy przeprowadzonej na wydzielonej części konstrukcji dachu, dla jednego wybranego obciążenia, trudno jednoznacznie określić, w jakiej postaci powinien pozostać szkielet. Należy pamiętać, że dach wagonu kolejowego stanowi ważny element konstrukcji w przeniesieniu podstawowych obciążeń eksploatacyjnych. Dopiero przeanalizowanie całej konstrukcji nośnej pudła może dać pełną odpowiedź na pytanie, jak powinien być ukształtowany szkielet.

\section{Literatura}

[1] Mielniczuk J., Malinowski M.: Modele materiatów porowatych $w$ projektowaniu konstrukcyjnych elementów powierzchniowych. Pojazdy Szynowe, Nr 3/2005.

[2] Mielniczuk J., Malinowski M., Kuligowski P.: Elementy powierzchniowe o strukturze porowatej w konstrukcji dachów pojazdów szynowych. Pojazdy Szynowe, Nr 2/2006. 